\title{
Halophilic microorganisms in deteriorated historic buildings: insights into their characteristics*
}

\author{
Justyna Adamiak ${ }^{\bowtie}$, Anna Otlewska, Beata Gutarowska and Anna Pietrzak \\ Institute of Fermentation Technology and Microbiology, Lodz University of Technology, Łódź, Poland
}

Historic buildings are constantly being exposed to numerous climatic changes such as damp and rainwater. Water migration into and out of the material's pores can lead to salt precipitation and the so-called efflorescence. The structure of the material may be seriously threatened by salt crystallization. A huge pressure is produced when salt hydrates occupy larger spaces, which leads at the end to cracking, detachment and material loss. Halophilic microorganisms have the ability to adapt to high salinity because of the mechanisms of inorganic salt $(\mathrm{KCl}$ or $\mathrm{NaCl})$ accumulation in their cells at concentrations isotonic to the environment, or compatible solutes uptake or synthesis. In this study, we focused our attention on the determination of optimal growth conditions of halophilic microorganisms isolated from historical buildings in terms of salinity, $\mathrm{pH}$ and temperature ranges, as well as biochemical properties and antagonistic abilities. Halophilic microorganisms studied in this paper could be categorized as a halotolerant group, as they grow in the absence of $\mathrm{NaCl}$, as well as tolerate higher salt concentrations (Staphylococcus succinus, Virgibacillus halodenitrificans). Halophilic microorganisms have been also observed (Halobacillus styriensis, H. hunanensis, $H$. naozhouensis, $H$. litoralis, Marinococcus halophilus and yeast Sterigmatomyces halophilus). With respect to their physiological characteristics, cultivation at a temperature of $25-30^{\circ} \mathrm{C}, \mathrm{pH} 6-7, \mathrm{NaCl}$ concentration for halotolerant and halophilic microorganisms, $0-10 \%$ and $15-30 \%$, respectively, provides the most convenient conditions. Halophiles described in this study displayed lipolytic, glycolytic and proteolytic activities. Staphylococcus succinus and Marinococcus halophilus showed strong antagonistic potential towards bacteria from the Bacillus genus, while Halobacillus litoralis displayed an inhibiting ability against other halophiles.

Key words: halophilic microorganisms, historic buildings, phenotypic characteristics, biodeterioration

Received: 07 August, 2015; revised: 19 October, 2015; accepted: 02 November, 2015; available on-line: 18 February, 2016

\section{INTRODUCTION}

Excessive moisture, and high salinity are the key factors contributing to the growth of halophilic microorganisms, a unique group of organisms which are able to grow at high salt concentrations. Many classification schemes have been designed according to their response to salt (slightly halophilic: $0.2-0.5 \mathrm{M}$ salt, moderately halophilic: 0.5-2.5 M salt, or extremely halophilic: 2.5$5.2 \mathrm{M}$ salt, and halotolerant strains: not requiring salt for growth but also grow at high salt concentrations). Halo- philic microorganisms have developed two mechanisms which determine their tolerance to high salinity. On one hand, they can accumulate inorganic ions (usually $\mathrm{K}^{+}$ and $\mathrm{Cl}^{-}$) at isotonic concentrations to the surrounding environment, but on the other hand, they can use the so-called compatible solute strategy in osmo-adaptation, based on the uptake or synthesis of organic molecules (e.g. sugars, polyols, amino acids, ectoine) (Madigan \& Oren, 1999; Xiang et al., 2008; Averhoff \& Müller, 2010). They have adapted to grow in many different niches (Laiz et al., 2000). Even though saline environment refers to water, considerable research has been carried out on halophiles inhabiting historic buildings (Rölleke et al., 1998; Heyrman et al., 1999; Laiz et al., 2000, 2001; Piñar et al., 2001, 2014; Ripka et al., 2006; Ettenauer et al., 2014).

Many of the historic buildings show signs of excessive moisture and salt efflorescence, which intensifies the corrosion processes, leading to the destruction of the building. Hence, historic buildings provide the environment convenient to the development and proliferation of halophilic microorganisms. Frequently, historic buildings are colonized by bacteria, whose representatives are Gammaproteobacteria (e.g. Idiomarina sp., Salinisphaera sp., Halomonas sp.), Firmicutes (e.g. Halobacillus sp., Bacillus sp.) and Actinobacteria (e.g. Rubrobacter sp.), or archaea (e.g. Halococcus sp., Halobacterium sp.). Halophilic fungi (e.g. Wallemia sp., Eurotium sp.) are in the minority (Piñar et al., 2014b; Sterflinger et al., 2014). Within the decayed materials, soluble salts such as carbonates, chlorides, nitrates or sulphates are dispersed. They migrate through the stone with capillary water, and as a result of changing physical parameters, the solution dries out causing the formation of salt deposits on the surface, known as salt efflorescence (Saiz-Jimenez \& Laiz, 2000; Ettenauer et al., 2010). Salt crystallization process accompanying the development of halophilic microorganisms causes destruction, crushing and cracking of historic buildings. Lazar (1971) and Bassi \& Giacobini (1973) suggested the biological origin of salt efflorescence, apart from a chemical one, and therefore it is important to check conditions that favour growth of halophiles. Halophiles are also responsible for aesthetic changes on surfaces, which is due to their ability of pigment formation, in particular carotenoids, that ultimately leads to the occurrence of characteristic colored biofilms (pink, orange, red) (Lo-

e-mail: justyna.adamiak@dokt.p.lodz.pl

*The results were presented at the 6th International Weigl Conference on Microbiology, Gdańsk, Poland (8-10 July, 2015).

Abbreviations: DGGE, denaturing gradient gel electrophoresis; PCA, Principal Component Analysis; PCR, polymerase chain reaction; TSB, Tryptic Soy Broth; M, mol/dm ${ }^{3}$; $\mathrm{McF}$, McFarland scale; \% $\mathrm{w} / \mathrm{v}$, weight/volume percentage concentration 
banova et al., 2008; Laiz et al., 2009; Jurado et al., 2012; Ettenauer et al., 2014).

The need to improve the condition of historic monuments plays a significant role, hence it is advisable to supplement the knowledge necessary to implement effective restoration and preservation methods with a microbiological aspect, taking into consideration especially halophiles. Unfortunately, using unsuitable media with inappropriate salt concentrations and improper incubation strategy has consequently led to their absence of growth under standard laboratory conditions, and hence resulted in their being overlooked. Although molecular techniques based on PCR reaction, DGGE analysis and clone library construction approach led to the great increase in our knowledge about halophilic microbial communities inhabiting cultural assets (Piñar et al., 2013; Otlewska et al., 2015), in order to obtain the entire information about biodeterioration, it is still important to get an overview on the halophilic organisms' culture conditions and phenotypic features. With this background, the current work was aimed to determine optimal growth conditions of halophilic microorganisms in terms of salinity, $\mathrm{pH}$ and temperature ranges, as well as biochemical properties and antagonistic abilities.

\section{MATERIALS AND METHODS}

Strains of halophilic microorganisms. Nine strains of microorganisms used in this investigation were isolated from brick, plaster and paint coatings collected from the former Auschwitz II-Birkenau concentration and extermination camp in Oświęcim, and 19th century chateau in Lódź, Poland (Table 1) with visible symptoms of dampness and salt efflorescence. Salinity of the samples was determined by a spectrophotometric method [\% sample mass]. Pure cultures were cultivated on TSA medium with both, $10 \% \mathrm{NaCl}(\mathrm{w} / \mathrm{v})$ and $2 \%$ $\mathrm{MgSO}_{4} \times 7 \mathrm{H}_{2} \mathrm{O}(\mathrm{w} / \mathrm{v})$, and incubated aerobically at $30^{\circ} \mathrm{C}$ for 5 days. The frequency of occurrence of each strain was investigated.

Optimal growth conditions determination. $\mathrm{pH}$ profile. Growth at different $\mathrm{pH}$ ranges was determined on TSB medium supplemented with $10 \% \mathrm{NaCl}$ $(\mathrm{w} / \mathrm{v})$ and $2 \% \quad \mathrm{MgSO}_{4} \times 7 \mathrm{H}_{2} \mathrm{O}(\mathrm{w} / \mathrm{v})$, wherein the $\mathrm{pH}$ was adjusted from 1 to 12 for each strain. The cultures were incubated at $30^{\circ} \mathrm{C}$ for 5 days. Every 24 hours, a turbidity measurement was performed using a densitometer in order to check the concentration of cells in McFarland scale $\left({ }^{\circ} \mathrm{McF}\right)$.

Table 1. Halophilic microorganisms considered in the study

\begin{tabular}{|c|c|c|c|}
\hline Strains & Inhabited area & Salinity of inhabited area ( $\%$ mass sample) & Relative abundance (\%) \\
\hline Halobacillus styriensis & \multirow{3}{*}{ brick $^{1}$} & \multirow{3}{*}{0.28} & 8 \\
\hline Halobacillus naozhouensis & & & 50 \\
\hline Halobacillus litoralis & & & 40 \\
\hline Staphylococcus succinus & \multirow{2}{*}{ brick $^{2}$} & \multirow{2}{*}{0.73} & 3 \\
\hline Halobacillus hunanensis & & & 16 \\
\hline Marinococcus halophilus & \multirow{2}{*}{ brick $^{3}$} & \multirow{2}{*}{1.55} & 7 \\
\hline Sterigmatomyces halophilus $\mathrm{H} 18$ & & & 4 \\
\hline Virgibacillus halodenitrificans & \multirow{2}{*}{ plaster with paint coatings 4} & \multirow{2}{*}{0.82} & 44 \\
\hline Sterigmatomyces halophilus $\mathrm{H} 11$ & & & 26 \\
\hline
\end{tabular}

1 - samples collected from historical buildings located in the former Auschwitz II-Birkenau concentration and extermination camp. 2, 3, 4 - sam-
Salinity profile. Tolerance to $\mathrm{NaCl}$ or $\mathrm{MgSO}_{4}$ was studied on TSB medium supplemented with $2 \%$ $\mathrm{MgSO}_{4} \times 7 \mathrm{H}_{2} \mathrm{O}(\mathrm{w} / \mathrm{v})$, where the $\mathrm{NaCl}$ concentration ranged from $0-30 \%(\mathrm{w} / \mathrm{v})$; or $5 \% \mathrm{NaCl}(\mathrm{w} / \mathrm{v})$, where the $\mathrm{MgSO}_{4} \times 7 \mathrm{H}_{2} \mathrm{O}$ concentration ranged from $0-30 \%$ $(\mathrm{w} / \mathrm{v})$, respectively. The cultures were incubated at $30^{\circ} \mathrm{C}$ for 5 days. A turbidity measurement was performed in the same way as described above.

Temperature profile. Growth temperature was tested in the range of $4,10,25,30,37$ and $44^{\circ} \mathrm{C}$ on TSA medium supplemented with $10 \% \mathrm{NaCl}(\mathrm{w} / \mathrm{v})$ and $2 \%$ $\mathrm{MgSO}_{4} \times 7 \mathrm{H}_{2} \mathrm{O}(\mathrm{w} / \mathrm{v})$, or $10 \% \mathrm{MgSO}_{4} \times 7 \mathrm{H}_{2} \mathrm{O}(\mathrm{w} / \mathrm{v})$ and $5 \% \mathrm{NaCl}(\mathrm{w} / \mathrm{v})$. Plates were incubated for 5 days.

Biochemical characterization. The utilization of a variety of substrates was tested using commercial API $50 \mathrm{CH}$ system (bioMérieux, France) while enzymatic activities were detected with API ZYM test (bioMérieux, France). API tests were performed following the manufacturer's instructions. The approximate number of free nmol hydrolyzed substrate may be estimated according to Nowak \& Piotrowska (2012): 0 - no activity; 1 $(5 \mathrm{nmol})$ and $2(10 \mathrm{nmol})$ - weak activity; 3 (20 nmol), $4(30 \mathrm{nmol})$, and 5 ( $\geq 40 \mathrm{nmol})$ - strong activity.

Antagonistic properties of halophilic microorganisms. For detection of antagonistic activity of halophilic isolates, a diffusion method was applied. Tested strains included other halophilic microorganisms considered in this study, as well as heterotrophic bacteria of the $B a$ cillus genus (B. cereus, B. muralis, B. simplex, B. atrophaeus), which according to the literature are known to inhabit historic buildings (Laiz et al., 2000; Saiz-Jimenez \& Laiz, 2000; Koziróg et al., 2014; Rajkowska et al., 2014). Bacillus strains, just as halophilic microorganisms, were isolated from historical sites, and based on 16S rRNA sequencing clustered to the Bacillus genus (Piotrowska et al., 2014). Using a $10 \mathrm{~mm}$ diameter sterile cork borer, the growing edge of 5-day culture of halophilic microorganisms was aseptically cut and placed at the plate already inoculated with the antagonist being tested. Bacteria of the Bacillus genus were plated on TSA medium, while halophilic microorganisms on TSA medium supplemented with $10 \%$ $\mathrm{NaCl}(\mathrm{w} / \mathrm{v})$ and $2 \% \mathrm{MgSO}_{4} \times 7 \mathrm{H}_{2} \mathrm{O}(\mathrm{w} / \mathrm{v})$. Plates were incubated at $30^{\circ} \mathrm{C}$ and monitored for 5 days. Measurement of inhibition ( $\mathrm{mm}$ ) was taken.

Statistical analysis. The relationship between optimal growth conditions of halophilic microorganisms, as well as their biochemical and enzymatic properties, were performed by Principal Component Analysis (PCA) and phenograms using Statistica v.10.0 (Stat Soft. Inc., USA) software.

\footnotetext{
ples collected from 19th century chateau in Łódź
} 


\section{RESULTS AND DISCUSSION}

\section{Optimal growth conditions determination}

Bacteria of the Staphylococcus succinus, Virgibacillus halodenitryficans, Marinococcus halophilus and Halobacillus litoralis species showed the widest $\mathrm{pH}$ range, up to 9 (Table S1 Supplementary Materials at www.actabp.pl). Regardless of the medium, optimum $\mathrm{pH}$ for the studied halophilic microorganisms occurred between 6-7, similarly to what was reported by Spring et al. (1996), Ventosa et al., (1998) and Ripka et al. (2006). They noted an increase in the counts of halophilic microorganisms of the Halobacillus genus in the $\mathrm{pH}$ range from 6 to 9.5, while the optimum was between 7.5-8.0. The majority of identified halophilic or halotolerant microorganisms grew best in media with pH from 6.8 to 7.5 (Vreeland et al., 2002; Caton et al., 2004; Schneegurt, 2012). It should be noted, however, that the authors did not observe the growth capacity below 6 and above 9.5. Nevertheless, historic buildings are unusual environment for the growth of halophiles, which typically inhabit saline lakes, marine and inland salterns, saline soils and salted foods (Ettenauer et al., 2010; Ventosa et al., 2012; Piñar et al., 2014a), and as a consequence, it may influence their optimal growth $\mathrm{pH}$ values. Building materials are generally characterised by alkaline $\mathrm{pH}$, however, due to biocorrosion it may be lowered (Beech \& Gaylarde, 1999; Warscheid \& Braams, 2000).

Optimum growth for all analysed strains occurred at $25-30^{\circ} \mathrm{C}$ both on medium supplemented with $10 \% \mathrm{NaCl}$ and $10 \% \mathrm{MgSO}_{4} \times 7 \mathrm{H}_{2} \mathrm{O}$ (Table S1 Supplementary Materials at www.actabp.pl). Growth in the widest range of temperature $\left(4-37^{\circ} \mathrm{C}\right)$ was shown, as previously reported, by Staphylococcus succinus and Virgibacillus halodenitryficans. According to the literature, halophilic bacteria- Halobacillus litoralis, $H$. trueperi and $H$. balophilus, can grow at a wide range of temperatures, from 10 to $43^{\circ} \mathrm{C}$. Their optimal growth is estimated at around $37^{\circ} \mathrm{C}$ (Spring et al., 1996; Ventosa et al., 1998; Ripka et al., 2006), while in contrast, optimum temperature for Halobacillus naozhouensis is $25^{\circ} \mathrm{C}$ (Chen et al., 2009). Usually halophiles are grown at room or slightly elevated temperature (25$30^{\circ} \mathrm{C}$ ) (Oren, 1986; Caton et al., 2004; Schneegurt, 2012).

Taking into consideration the response to high salinity, as reported by Kushner \& Kamekura (1988) and Joo \& $\operatorname{Kim}$ (2005), the investigated microorganisms were divided into halophilic and halotolerant which requires salt for growth or are able to grow in the absence of salt, respectively. The group of halophilic microorganisms included: Halobacillus styriensis, H. hunanensis, H. naozhouensis, $H$. litoralis, Marinococcus halophilus, and Sterigmatomyces halophilus. Optimum growth occurred in media supplemented with 15-30\% (w/v) NaCl (Table S1 Supplementary Materials at www.actabp.pl). No growth was observed without halite supplementation. In contrast, for halotolerant species (Staphylococcus succinus, Virgibacillus halodenitrificans) optimal salinity range was $0-15 \%$ and $0-10 \%$ (w/v) $\mathrm{NaCl}$, respectively (Table S1 Supplementary Materials at www.actabp.pl). Bacteria of the genus Halobacillus ( $H$. litoralis, $H$. halophilus and $H$. trueper $)$, known as moderately halophilic was observed to grow in a wide range of $\mathrm{NaCl}$ concentration $(0.5-25 \%)$, but the optimum growth was estimated at $10 \% \mathrm{NaCl}$ (Spring et al., 1996; Ventosa et al., 1998; Ripka et al., 2006). Salt concentration plays crucial role in media composition. Ettenauer et al. (2014) for the cultivation of halophilic microorganisms isolated from the Johannes Chapel in Pürgg used media supplemented with $15 \% \mathrm{NaCl}(\mathrm{w} / \mathrm{v})$ whereas Piñar et al. (2014a) for the cultivation of halophilic bacteria colonizing the exhibition areas of the Capuchin Catacombs in Palermo applied media with three different $\mathrm{NaCl}$ concentrations $3 \%, 10 \%$ and $20 \%(\mathrm{w} / \mathrm{v})$.

The primary component of efflorescence is not always halite $(\mathrm{NaCl})$, because salinity can also be based on epsomite $\left(\mathrm{MgSO}_{4} \times 7 \mathrm{H}_{2} \mathrm{O}\right)$, gypsum $\left(\mathrm{CaSO}_{4} \times 2 \mathrm{H}_{2} \mathrm{O}\right)$, nitrate $\left(\mathrm{NaNO}_{3}\right)$ and other salts (Saiz-Jimenez, 2000). Because of the specific composition of salt efflorescence it was found necessary either to check the capacity of analysed strains to grow at various $\mathrm{MgSO}_{4}$ (epsomite) concentration, however, no significant changes were detected (Table S1 Supplementary Materials at www.actabp.pl). Slightly poorer growth was observed when the concentration exceeded 15\% (w/v). Laiz et al. (2000) detected that $1 \%$ to $10 \%(\mathrm{w} / \mathrm{v})$ epsomite concentration favoured

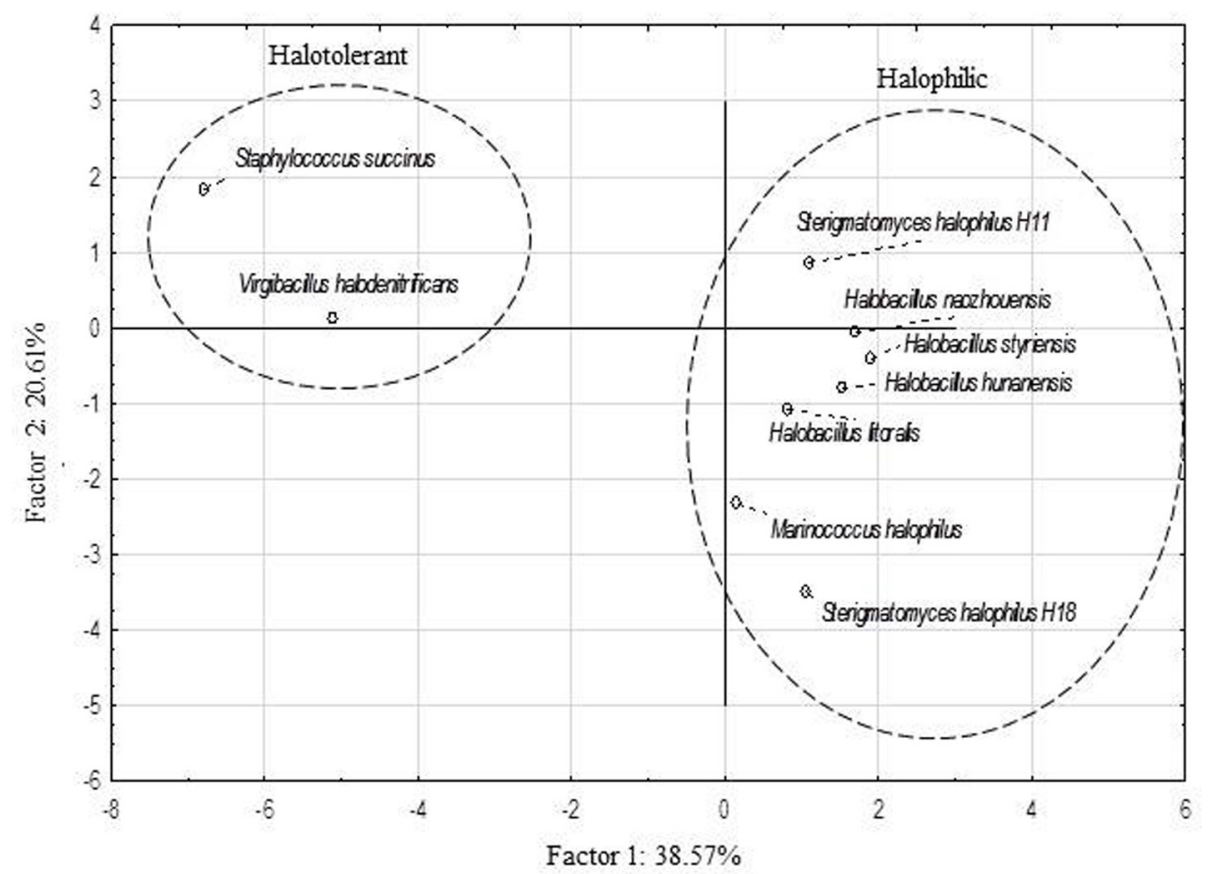

Figure 1. Principal Component Analysis (PCA) concerning $\mathrm{pH}$, temperature, halite and epsomite concentration ranges for all studied halophilic/halotolerant microorganisms 
Sterigmatomyces halophilus $\mathrm{H} 18$

Marinococcus halophilus

Halobacillus hunanensis

Sterigmatomyces halophilus $\mathrm{H} 11$

Halobacillus litoralis

Halobacillus naozhouensis

Halobacillus styriensis

Virgibacillus halodenitryficans

Staphylococcus succinus
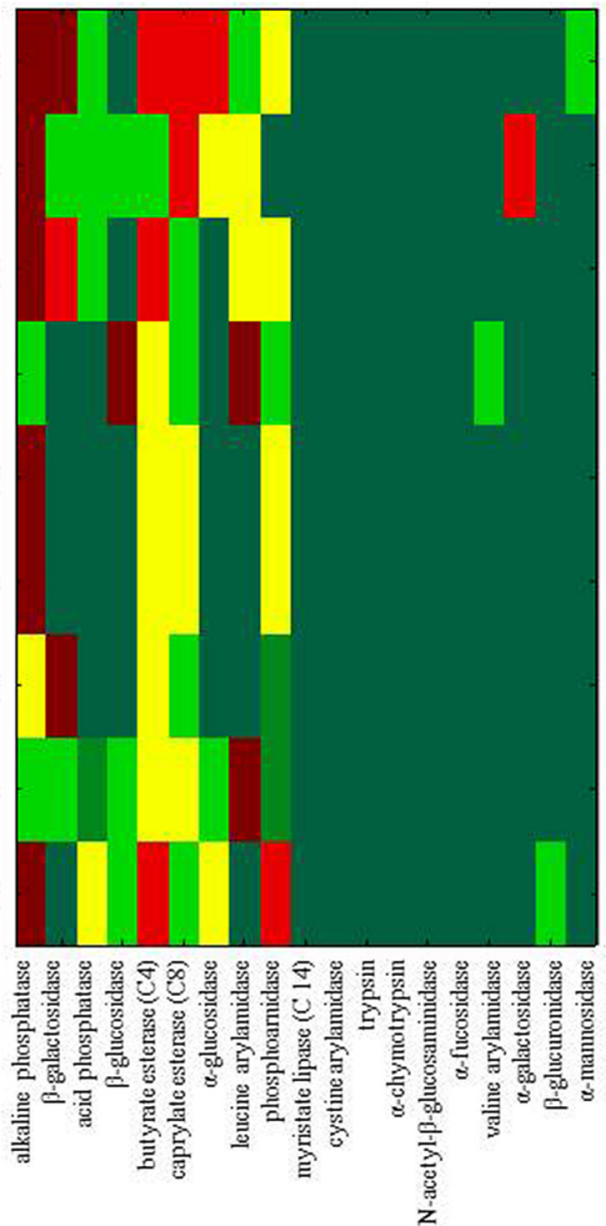

$>40 \mathrm{nmol}$

$30 \mathrm{nmol}$

$20 \mathrm{nmo}$

$10 \mathrm{nmol}$

$5 \mathrm{nmol}$

no activity

Figure 2. Enzymatic activities of selected strains

Staphylococcus succinus

Sterigmatomyces halophilus $\mathrm{H} 18$

Sterigmatomyces halophilus H11

Virgibacillus halodenitryficans

Halobacillus styriensis

Halobacillus hunanensis

Halobacillus naozhouensis

Halobacillus litoralis

Marinococcus halophilus

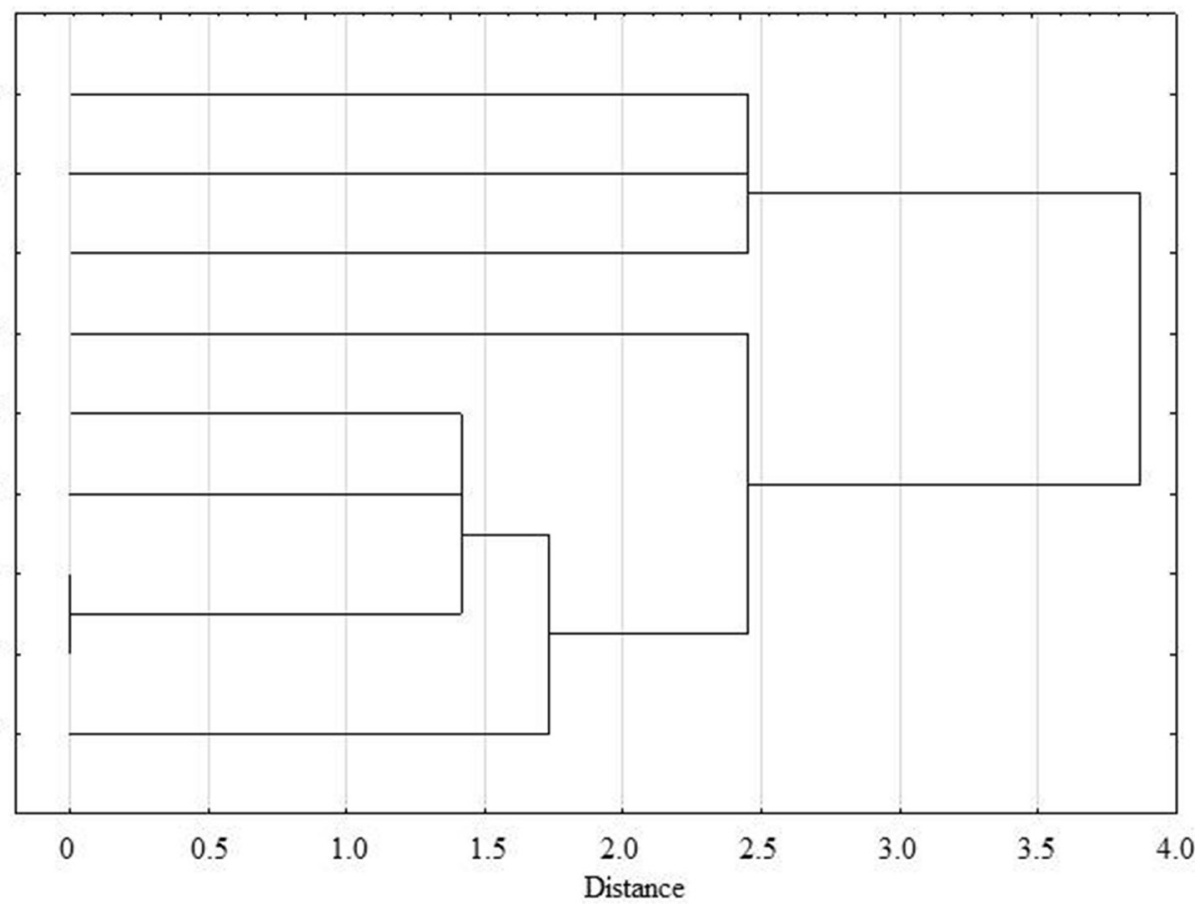

Figure 3. Phenogram showing similarity between studied halophilic/halotolerant microorganisms based upon utilisation of a variety of substrates 


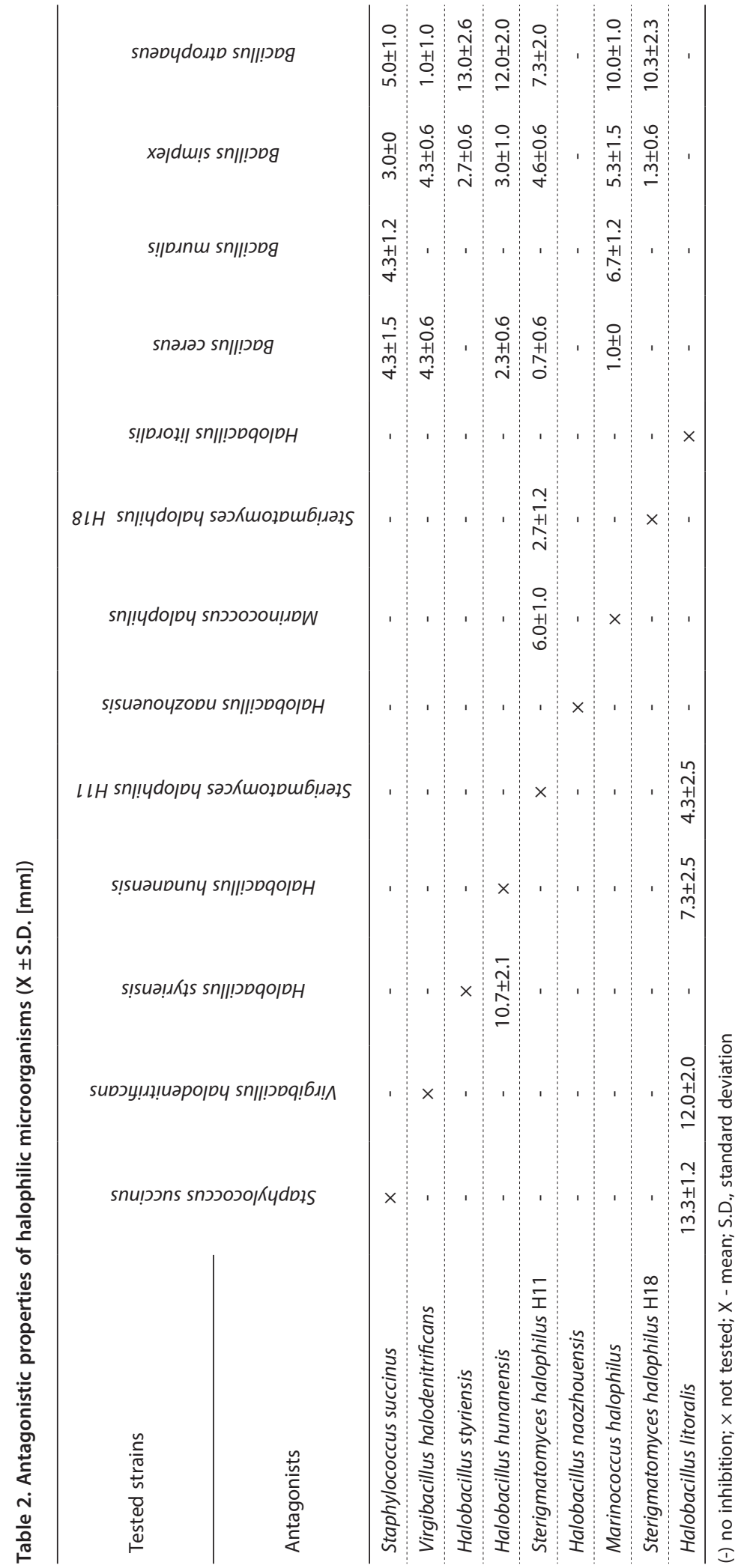

their differences or similarities. For that purpose, Principal Component Analysis (PCA) was performed (Fig. 1). An interesting observation is division of the organisms into two groups: members of the first one are Halobacillus sp. $(H$. litoralis, $H$. styriensis, $H$. bunanenis, H. naozhouensis), Sterigmatomyces halophilus, Marinococcus balophilus, whereas the second one consists of Virgibacillus halodenitryficans and Staphylococcus succinus. This corresponds with an established scheme, according to response to high salinity, proposed by Kushner \& Kamekura (1988) and Joo \& Kim (2005). The first group involves halophilic microorganisms, the second group halotolerant ones.

\section{Biochemical properties}

Enzymatic activities of selected strains are shown in Table S2 (Supplementary Materials at www.actabp. $\mathrm{pl}$ ) and Fig. 2. All tested strains synthesized alkaline phosphatase; 8 out of 10 microorganisms (except from Virgibacillus halodenitryficans and Sterigmatomyces balophilus H11) displayed its strong activity. Our findings are similar to the results published by Jurado et al. (2012), who observed alkaline phosphatase activity in strains isolated from biodeteriorated monuments, and Chen et al. (2009) who detected that Halobacillus naozhouensis synthesized this enzyme. Almost all analysed halophilic microorganisms displayed a strong butyrate esterase activity (excluding $\mathrm{Ma}$ rinococcus balophilus), but on the other hand weak caprylate esterase activity. López-Miras et al. (2013) found that Virgibacillus sp., inhabiting oil painting showing signs of biodeterioration, produced esterases cleaving 2-naphtylbutyrate and 2-naphtylcaprylate. None of the strains hydrolyzed ester linkage in 2-naphtylmirystate (myristate lipase activity). Only one out of 5 peptide hydrolases (leucine, valine, and cystine arylamidases, and trypsin and $\alpha$-chymotrypsin) was detected. Virgibacillus halodenitryficans and Sterigmatomyces halophilus H11 synthesized leucine arylamidase (strong activity). Proteases synthesised by halophilic microorganisms were applied in industry (Karbalaei-Heidari et al., 2009; Yin et al., 2014). Three enzymes involved in carbohydrate metabolism were detected: $\beta$-galactosidase (Halobacillus styriensis, $H$. hunanensis and Sterigmatomyces halophilus H18 strongly produced this enzyme), $\alpha$-glucosidase (synthesised mainly by Staphylococcus succinus, Marinococcus balophilus and Sterigmatomyces halophilus H18) and $\beta$-glucosidase (Sterigmatomyces halophilus H11). It is worth to note that almost all strains (excluding Marinococcus balophilus) synthesised a phosphoamidase, which with reference to López-Miras et growth of halophiles, which resulted in increasing number of colony forming units (up to $48.3 \times 10^{3} \mathrm{cfu} / \mathrm{g}$ ) with respect to medium without $\mathrm{MgSO}_{4} \times 7 \mathrm{H}_{2} \mathrm{O}$.

The next goal of this research was to compress data concerning $\mathrm{pH}$, temperature, halite and epsomite concentration ranges for all studied halophilic microorganisms, and in particular to classify them by highlighting 
al. (2013), was found to be excreted by Bacillus sp. inhabiting historic paintings. The same enzymatic pattern was obtained only for Halobacillus naozhouensis and Halobacillus litoralis (Fig. 2).

Among studied halophilic microorganisms, Staphylococcus succinus was able to utilise the widest variety of substrates (25 out of 49 tested substrates; Table S3 Supplementary Materials at www.actabp.pl) as a sole source of carbon, nitrogen and energy, and this strain may become a serious threat for historic buildings (Table S3 Supplementary Materials at www.actabp.pl) (Chen et al., 2009; López-Miras et al., 2013). Halophilic yeast Sterigmatomyces halophilus was able to utilise 23 substrates, while in contrast Halobacillus ssp. and Marinococcus balophilus utilized between 1 and 3, depending on the species. Phenogram based on utilisation of a variety of substrates (Fig. 3), shows the relationship between halophilic microorganisms and their biochemical properties. H. naozhouensis and $H$. litoralis presented the same biochemical profile, while other strains were more dissimilar.

\section{Antagonistic properties of halophilic microorganisms}

Staphylococcus succinus and Marinococcus balophilus were the most effective in inhibiting the growth of all tested bacterial strains from the Bacillus genus, while the least effective were $H$. naozhouensis and $H$. litoralis, which were not able to inhibit growth of any of the above mentioned strains (Table 2). In contrast, the inhibiting ability of Halobacillus litoralis against other halophilic microorganisms (Staphylococcus succinus, Virgibacillus halodenitryficans, Halobacillus bunanensis and Sterigmatomyces halophilus H11) considered in this study was observed. The members of the Halobacillus genus represent the majority of detected halophilic microorganisms in historic buildings, which may be explained by remarkable osmotic adaptation of bacilli (Piñar et al., 2009).

\section{CONCLUSIONS}

Cultivation at temperatures of $25-30^{\circ} \mathrm{C}, \mathrm{pH} 6-7$, and $\mathrm{NaCl}$ concentration for halotolerant/halophilic microorganisms, $0-10 \%$ and $15-30 \%$ respectively, provides the optimum conditions for their growth. For the successful isolation of halophiles, it is therefore necessary to use specific media with high salt concentration and to apply appropriate incubation strategy. Halophiles described in this study displayed a strong lipolytic activity, as well as weaker glycolytic and proteolytic activities. Two strains, Staphylococcus succinus and Marinococcus halophilus, showed antagonistic potential towards bacteria from the Bacillus genus, while Halobacillus litoralis displayed an inhibiting ability against other halophiles.

\section{REFERENCES}

Averhoff B, Müller V (2010) Exploring research frontiers in microbiology: recent advances in halophilic and thermophilic extremophiles. Res Microbiol 161: 506-514. doi: 10.1016/j.resmic.2010.05.006.

Bassi M, Giacobini C (1973) Scanning electron microscopy: a new technique in the study of the microbiology of work of art. Int Biodet Bull 9: 57-68. doi: 10.1016/S0964-8305(01)00066-X.

Beech I, Gaylarde C (1999) Recent advances in the study of biocorrosion - an overview. Rev. Microbiol. 30: 177-190. doi: 10.1590/ S0001-37141999000300001.

Caton TM, Witte LR, Ngyuen HD, Buchheim JA, Buchheim MA, Schneegurt MA (2004) Halotolerant aerobic heterotrophic bacteria from the Great Salt Plains of Oklahoma. Microb Ecol 48: 449-462. doi: 10.1007/s00248-004-0211-7.

Chen YG, Liu ZX, Zhang YQ, Zhang YX, Tang SK, Borrathybay E, Li WJ, Cui XL (2009) Halobacillus naozhouensis sp. nov., a moderately halophilic bacterium isolated from a sea anemone. Antonie V an Leeuwenhoek 96: 99-107. doi: 10.1007/s10482-009-9340-9.

Ettenauer J, Sterflinger K, Piñar G (2010) Cultivation and molecular monitoring of halophilic microorganisms inhabiting an extreme environment presented by a salt-attacked monument. Int J Astrobiology 9: 59-72. doi: 10.1017/S1473550409990383.

Ettenauer J, Jurado V, Piñar G, Miller AZ, Santner M, Saiz-Jimenez C, Sterflinger K (2014) Halophilic microorganisms are responsible for the rosy discolouration of saline environments in three historical buildings with mural paintings. PLOS ONE 9: 1-13. doi: 10.1371/ journal.pone. 0103844 .

Heyrman J, Mergaert J, Denys R, Swings J (1999) The use of fatty acid methyl ester analysis (FAME) for the identification of heterotrophic bacteria present on three mural paintings showing severe damage by microorganisms. FEMS Microbiol Lett 181: 55-62. doi: 10.1111/ j.1574-6968.1999.tb08826.x.

Yin J, Chen JC, Wu Q, Chen GQ (2014) Halophiles, coming stars for industrial biotechnology. Biotechnol $A d v$, in press. doi:10.1016/j.biotechadv.2014.10.008.

Joo WA, Kim CW (2005) Proteomics of halophilic archaea. J Chromatogr B 815: 237-250. doi: 10.1016/j.jchromb.2004.10.041.

Jurado V, Miller AZ, Alias-Villegas C, Laiz L, Saiz-Jimenez C (2012) Rubrobacter bracarensis sp. nov., a novel member of genus Rubrobacter isolated from a biodeteriorated monument. Syst Appl Microbiol 35: 306-309. doi: 10.1016/j.syapm.2012.04.007.

Karbalaei-Heidari HR, Amoozegar MA, Ziaee AA (2009) Production, optimization and purification of a novel extracellular protease from the moderately halophilic bacterium. Ind Microbiol Biotechnol 36: $21-$ 27. doi: 10.1007/s10295-008-0466-y.

Koziróg A, Otlewska A, Piotrowska M, Rajkowska K, Nowicka-Krawczyk P, Hachułka M, Wolski GJ, Gutarowska B, Kunicka-Styczyńska A, Libudzisz Z, Żakowska Z, Żydzik-Białek A (2014) Colonising organisms as a biodegradation factor affecting historical wood materials at the former concentration camp of Auschwitz II-Birkenau. Int Biodeterior Biodegradation 86: 171-178. doi: 10.1016/j. ibiod.2013.08.004.

Kushner DJ, Kamekura M (1988) Physiology of halophilic eubacteria. In Halophilic Bacteria. Rodriguez-Valera F ed, pp 109-138, CRC Press Boca Raton, Florida.

Laiz L, Recio D, Hermosin B, Saiz-Jimenez C (2000) Microbial communities in salt efflorescences. In Of Microbes and Art. Cifferi O, Tiano P, Mastromei G eds, pp 77-88, Springer. doi: 10.1007/9781-4615-4239-1_6.

Lazar I (1971) Investigations on the presence and role of bacteria in deteriorated zones of Cozia monastery painting. Rev Roum Biol Bot 16: $437-444$.

Lobanova KV, Kerbalaeva AM, Tashpulatov ZZ, Gulyamova TG (2008) Carotene-forming activity of certain halophilic bacteria from Barsakelmes saline soil. Chem Nat Compd 44: 306-307. doi: 10.1007/ s10600-008-9048-5.

López-Miras M, Piñar G, Romero-Noguera J, Bolivar-Galiano FC, Ettenauer J, Sterflinger K, Martin-Sanchez I (2013) Microbial communities adhering to the observe and reverse sides of oil painting on canvas: identification and evaluation of their biodegradative potential. Aerobiologia 29: 301-314. doi: 10.1007/s10453-012-9281-z.

Madigan MT, Oren A (1999) Thermophilic and halophilic extremophiles. Curr Opin Microbiol 2: 265-269. doi: 10.1016/S13695274(99)80046-0.

Márquez MC, Ventosa A, Ruiz-Berraquero F (1992) Phenotypic and chemotaxonomic characterization of Marinococcus balophilus. Syst Appl Microbiol 15:63-69. doi: 10.1016/S0723-2020(11)80140-2.

Nowak A, Piotrowska M (2012) Biochemical activities of Brochothrix thermosphacta. Meat Sci 90: 410-413. doi: 10.1016/j.meatsci.2011.08.008

Oren A (1986) Intracellular salt concentrations of the anaerobic halophilic eubacteria Haloanaerobium praevalens and Halobacteroides halobius. Can J Microbiol 32: 4-9. doi: 10.1139/m86-002.

Otlewska A, Adamiak J, Gutarowska B (2015) Clone-based comperative sequence analysis of $16 \mathrm{~S}$ rRNA genes retrieved from biodeteriorating brick buildings of the former Auschwitz II-Birkenau concentration and extermination camp. Syst Appl Microbiol 38: 48-55. doi: 10.1016/j.syapm.2014.09.003.

Piñar G, Ramos C, Rölleke S, Schabereiter-Gurtner C, Vybiral D, Lubitz W, Denner EBM (2001) Detection of indigenous Halobacillus population in damaged ancient wall paintings and building materials: molecular monitoring and cultivation. Appl Environ Microbiol 67: 4891-4895. doi: 10.1128/AEM.67.10.4891-4895.2001.

Piñar G, Ripka K, Weber J, Sterflinger K (2009) The micro-biota of a sub-surface monument the medival chapel of St. Virgil (Vienna, Austria). Int Biodeterior Biodegradation 63: 851-859. doi: 10.1016/j. ibiod.2009.02.004.

Piñar G, Piombino-Mascali D, Maixner F, Zink A, Sterflinger K (2013) Microbial survey of the mummies from the Capuchin Catacombs of Palermo, Italy: biodeterioration risk and contamination of the indoor air. FEMS Microbiol Ecol 86:341-356. doi: 10.1111/15746941.12165. 
Piñar G, Kraková L, Pangallo D, Piombino-Mascali D, Maixner F, Zink A, Sterflinger K (2014a) Halophilic bacteria are colonizing the exhibition areas of the Capuchin Catacombs in Palermo, Italy. Extremophiles 18: 677-691. doi: 10.1007/s00792-014-0649-6.

Piñar G, Ettenauer J, Sterflinger K (2014b) "La vie en rose": a review of rosy discoloration of subsurface monuments. In The conservation of subterranean cultural heritage. Saiz-Jimenez C ed, pp 113-123, Taylor and Francis Group.

Piotrowska M, Otlewska A, Rajkowska K, Koziróg A, Hachułka M, Nowicka-Krawczyk P, Wolski GJ, Gutarowska B, Kunicka-Styczyńska A, Żydzik-Białek A (2014) Abiotic determinants of the historical building biodeterioration in the former Auschwitz II-Birkenau concentration and extermination camp. PLOS ONE 9: 1-12. doi: 10.1371/journal.pone.0109402.

Rajkowska K, Otlewska A, Koziróg A, Piotrowska M, Nowicka-Krawczyk P, Hachułka M, Wolski GJ, Kunicka-Styczyńska A, Gutarowska B, Żydzik-Białek A (2014) Assessment of biological colonization of historic buildings in the former Auschwitz II-Birkenau concentration camp. Ann Microbiol 64: 799-808. doi: 10.1007/s13213-0130716-8.

Ripka K, Denner EBM, Michaelsen A, Lubitz W, Piñar G (2006) Molecular characterization of Halobacillus strain isolated from different medieval wall paintings and buildings material in Austria. Int Biodeterior Biodegradation 58: 124-132. doi: 10.1016/j.ibiod.2006.05.004.

Rölleke S, Witte A, Wanner G, Lubitz W (1998) Medieval wall painting - a habitat for archaea: identification of archaea by denaturing gradient gel electrophoresis (DGGE) of PCR-amplified gene fragments coding for $16 \mathrm{~S}$ rRNA in a medieval wall painting. Int Biodeterior Biodegradation 41: 85-92. doi: 10.1016/S0964-8305(98)80011-5.

Saiz-Jimenez C, Laiz L (2000) Occurrence of halotolerant/halophilic bacterial communities in deteriorated monuments. Int Biodeterior Biodegradation 46: 319-326. doi: 10.1016/S0964-8305(00)00104-9.
Schneegurt MA (2012) Media and Conditions for the Growth of Halophilic and Halotolerant Bacteria and Archaea. In Advances in Understanding the Biology of Halophilic Microorganisms. Vreeland RH ed, pp 35-58, Springer Netherlands. doi: 10.1007/978-94-007-5539-0_2.

Spring S, Ludwig W, Marquez MC, Ventosa A, Schleifer KH (1996) Halobacillus gen. nov., with descriptions of Halobacillus litoralis sp. nov. and Halobacillus trueperi sp. nov., and transfer of Sporosarcina halophila to Halobacillus halophilus comb. nov. Int J Syst Bacteriol 46: 492-496. doi: 10.1099/00207713-46-2-492.

Sterflinger K, Ettenauer J, Piñar G (2014) Microbes, art, science and conservation, who wins the game? In Science, technology and cultural beritage. Rogerio-Candelera MA ed, pp 191-204, Taylor and Francis Group.

Ventosa A, Nieto JJ, Oren A (1998) Biology of moderately halophilic aerobic bacteria. Microbiol Mol Biol R 62: 504-544.

Ventosa A, Márquez MC, Sánchez-Porro C, de la Haba R (2012) Taxonomy of halophilic archaea and bacteria. In Advances in Understanding the Biology of Halophilic Microorganisms. Vreeland RH ed, pp 59-80, Springer, Dordrecht. doi: 10.1007/978-94-007-5539-0_3.

Vreeland RH, Straight S, Krammes J, Dougherty K, Rosenzweig WD, Kamekura M (2002) Halosimplex carlsbadense gen. nov., sp. nov., a unique halophilic archaeon with three $16 \mathrm{~S}$ rRNA genes, that grows only in defined medium with glycerol and acetate or pyruvate. Extremophiles 6: 445-452. doi: 10.1007/s00792-002-0278-3.

Warscheid T, Braams J (2000) Biodeterioration of stone: a review. Int Biodeterior Biodegradation 46: 343-368. doi: 10.1016/S09648305(00)00109-8.

Xiang W, Guo J, Feng W, Huang M, Chen H, Zhao J, Zhang J, Yang Z, Sun Q (2008) Community of extremely halophilic bacteria in historic Dagong Brine Well in southwestern China. World J Microbiol Biotechnol 24: 2297-2305. doi: 10.1007/s11274-008-9744-0. 